\title{
PENGEMBANGAN INSTRUMEN PENILAIAN BERBASIS HOTS PADA MATERI PENGOLAHAN DATA DALAM KEHIDUPAN SEHARI-HARI UNTUK SISWA KELAS VI SD
}

\author{
I.W. Puwardana ${ }^{1}$, Sariyasa ${ }^{2}$, I.N. Suastika ${ }^{3}$ \\ ${ }^{123}$ Program Studi Pendidikan Dasar \\ Universitas Pendidikan Ganesha \\ Singaraja, Indonesia \\ e-mail: puwardana@undiksha.ac.id ${ }^{1}$, sariyasa@undiksha.ac.id ${ }^{2}$, \\ nengah.suastika@undiksha.ac.id $^{3}$
}

\begin{abstract}
Abstrak
Penelitian ini bertujuan untuk mengembangkan Instrumen Penilaian Berbasis HOTS pada Materi Pengolahan data dalam Kehidupan Sehari-hari yang valid, reliabel, objektiv, praktis, dan norma. Penelitian yang dilakukan adalah penelitian pengembangan (research and development) model 4D yang dipelopori oleh Thiagarajan terdiri atas 4 tahap yaitu define, design, develop dan desimination. Akan tetapi tahap desimination tidak dapat dilakukan karena adanya pandemi Covid 19 yang berdampak pada kesehatan masyarakat dan siswa. Penelitian ini menghasilkan instrumen Penilaian berbasis HOTS dalam bentuk soal pilihan ganda. Instrumen tersebut kemudian divalidasi oleh tim ahli yang berasal dari 2 dosen ahli matematika dan 3 orang praktisi guru Kelas VI SD. instrumen selanjutnya diujicobakan pada 30 siswa. Berdasarkan hasil validasi ahli maka instrumen dinyatakan valid dengan kategori sangat baik. Validitas isi tes dianalisis menggunakan analisis CVR didapatkan hasil valid untuk semua soal. Hasil validitas butir dianalisis menggunakan rumus point biserial diperoleh $r_{\text {hitung }}>r_{\text {tabel }}$ sehingga semua butir soal valid. Hasil uji reliabilitas tes diperoleh nilai sebesar 0,75 pada pengujian pertama dan 0,76 pada pengujian kedua. Hasil uji berada pada rentang $0,60<r_{1.1} \leq 0,80$ dengan kategori derajat reliabilitas yang "tinggi". Berdasarkan hasil uji objektivitas, praktikalitas dan norma didapat hasil instrument tes adalah objektif, sangat praktis dan norma. Berdasarkan hal tersebut dapat disimpulkan bahwa Instrumen berbasis HOTS yang dikembangkan valid, reliabel, Objektif, praktis, dan norma sehingga layak digunakan untuk mengukur kemampuan berpikir tingkat tinggi siswa.
\end{abstract}

Kata kunci: Instrumen; Materi Pengolahan Data; Penilaian HOTS

\begin{abstract}
This study aims to develop a HOTS-Based Assessment Instrument on Data Processing Materials in Daily Life that is valid, reliable, objective, practical, and normative. The research carried out is research and development of $4 D$ models pioneered by Thiagarajan consisting of 4 stages, namely define, design, develop and desimination. However, the desimination stage cannot be carried out due to the Covid 19 pandemic which has an impact on the health of the community and students. This study produced a HOTS-based assessment instrument in the form of multiple choice questions. The instrument was then validated by a team of experts consisting of 2 lecturers of mathematicians and 3 practicing teachers of sixth grade Elementary School. The instrument was then tested on 30 students. Based on the results of expert validation, the instrument is declared valid with a very good category. The validity of the test content was analyzed using CVR analysis and obtained valid results for all questions. The results of the validity of the items were analyzed using the biserial point formula obtained rcount > rtable so that all items were valid. The results of the test reliability test obtained a value of 0.75 in the first test and 0.76 in the second test. The test results are in the range of $0.60<r 1.1<0.80$ with a "high" reliability degree category. Based on the test results of objectivity, practicality and norms, the results of the test instruments are objective, very practical and norms. Based on this, it can be concluded that the HOTS-based instrument
\end{abstract}


developed is valid, reliable, objective, practical and normative so that it is feasible to be used to measure students' higher order thinking skills.

Keywords: Instrument; Data Processing; HOTS Penilaian

\section{PENDAHULUAN}

Manusia adalah makhluk ciptaan Tuhan yang diberikan kemampuan untuk bisa memilah mana yang benar dan mana yang salah melalui aktivitas berpikir. Perkembangan berpikir seseorang pada umumnya terjadi ketika melakukan aktivitas belajar. Aktivitas belajar tidak hanya dilakukan pada situasi pendidikan formal, namun juga bisa melalui kegiatan non-formal yang segera bisa dilakukan. Segala bentuk kegiatan belajar dengan melakukan aktivitas percobaan, menghadapi kesulitan, dan mampu mencari solusi dari permasalahan akan memperkaya proses pengalaman belajar. Melalui proses belajar, manusia dapat meningkatkan kualitas dalam dirinya sehingga manusia bisa dikatakan mempunyai nilai sebagai aktualisasi diri dalam menyikapi segala tantangan yang dihadapinya dalam kehidupan.

Upaya peningkatan kualitas sumber daya manusia erat kaitannya dengan peran lembaga pendidikan. Pendidikan merupakan bagian penting yang mampu menggambarkan kualitas kemajuan suatu bangsa. Pendidikan pada hakikatnya adalah serangkaian upaya pembudayaan, pemanusiaan dan pemberadaban manusia sebagai makhluk yang dipercaya sebagai khalifah di bumi ini. Sani, (2015) menyatakan pendidikan memberikan kemungkinan kepada siswa untuk memperoleh kesempatan, harapan dan pengetahuan agar dapat hidup secara lebih baik. Besarnya kesempatan dan harapan sangat bergantung pada kualitas pendidikan yang ditempuh. Pendidikan juga dapat menjadi kekuatan untuk melakukan perubahan agar sebuah kondisi menjadi lebih baik. Pendidikan yang berkualitas tentunya melibatkan siswa untuk aktif belajar dan mengarahkan terbentuknya nilai-nilai yang dibutuhkan oleh siswa dalam menempuh kehidupan. Proses Pendidikan tersebut merupakan esensi dari paradigma pembelajaran abad 21 yang ditandai dengan adanya perubahan perilaku manusia dari fase tradisional ke fase modern yang dibantu oleh penguasaan teknologi.

Paradigma pembelajaran Abad 21 merupakan kegiatan pembelajaran yang menekankan pada kemampuan siswa untuk berpikir kritis, mampu menghubungkan ilmu dengan dunia nyata, menguasai teknologi informasi komunikasi, dan berkolaborasi (Janah et al., 2019). Dalam prakteknya kegiatan pembelajaran seperti ini akan terjadi jika guru sebagai salah satu faktor penentu keberhasilan pembelajaran mampu mengemas kegiatan pembelajaran yang memungkinkan siswa untuk bisa mengembangkan kemampuan afektif, kognitif dan psikomotornya. Khusus untuk pengembangan kemampuan kognitif siswa maka diberlakukan kegiatan pembelajaran yang mengarah pada adanya aktifitas berpikir tingkat tinggi yang sekarang lazim disebut dengan istilah Higher Order Thinking Skills (HOTS).

Pada proses pembelajaran dilaksanakan kegiatan pembelajaran yang Berbasis HOTS (Higher Order of Thinking Skills) maka pada proses penilaian juga dikembangkan alat penilaian yang mengarah pada aktivitas HOTS. Hal ini bertujuan untuk menciptakan konsistensi antara kegiatan pembelajaran dengan kegiatan penilaian (evaluasi) yang dilakukan. Penilaian dalam pembelajaran adalah serangkaian kegiatan pengumpulan dan pengolahan informasi, untuk menentukan pencapaian hasil belajar siswa. Pencapaian hasil belajar siswa bisa diukur menggunakan alat ukur berupa tes tertulis yang disajikan dalam 
bentuk soal. Soal-soal yang disajikan tentunya harus mengarahkan siswa agar mampu mengembangkan kemampuan berpikir tingkat tinggi atau HOTS.

Kemampuan berpikir tingkat tinggi (HOTS) merupakan kemampuan yang wajib dimiliki oleh setiap siswa. Hal ini wajib karena kemampuan menganalisa, menilai maupun mengkreasi merupakan syarat untuk bisa mengikuti segala perubahan yang terjadi di jaman globalisasi sekarang ini. kemampuan menganalisis dan melakukan penilaian terhadap suatu permasalahan atau fenomena yang dihadapi membuat siswa mampu untuk menciptakan suatu metode praktis yang bisa digunakannya untuk mengatasi permasalahan yang dihadapinya itu. Kegiatan seperti itu bisa dilakukan oleh siswa Ketika guru lebih sering memberikan latihan-latihan soal yang penyelesaiannya menuntut siswa mengembangkan kemampuan Analisa, menilai maupun mengkreasi.

Berdasarkan kegiatan wawancara yang dilakukan dengan 5 orang guru Kelas VI SD di Gugus IV Kecamatan Tabanan yang dilakukan Tanggal 4 Februari 2021 didapatkan hasil bahwa guru mengalami kesulitan dalam merancang instrument penilaian atau soal yang berbasis HOTS khusus untuk Mata Pelajaran Matematika. Berdasarkan wawancara tersebut guru beranggapan instrument penilaian atau soal-soal yang sulit itu adalah soal yang HOTS. Instrumen penilaian atau soalsoal HOTS merupakan jenis soal yang menuntut aktivitas berpikir tingkat tinggi (Sofyan, 2019). Hal ini sesuai dengan pernyataan (Hanifah, 2017) yang menyatakan bahwa guru-guru pada umumnya memahami ada revisi dalam Kurikulum 2013 diantaranya harus mengembangkan HOTS dalam kegiatan pembelajaran termasuk dalam pengembangan instrumen penilaiannya, akan tetapi mereka mengalami kesulitan dalam merumuskan Indikator Pencapaian Kompetensi (IPK) yang mengarah pada proses pembelajaran dan penilaian yang berbasis HOTS.
Walaupun ada beberapa guru yang sudah memiliki kemampuan untuk merancang instrument penilaian yang Berbasis HOTS namun mereka kesulitan untuk membelajarkan siswa agar bisa berpikir ke tingkat yang lebih tinggi (analisis, evaluatif, mencipta). Hal ini sejalan dengan pendapatnya (Hidayati, 2017) yang menyatakan bahwa guru mengalami kebingungan untuk melatih siswa sekolah dasar agar dapat berpikir tingkat tinggi. Ini berarti bahwa instrumen hasil belajar baik yang digunakan oleh guru untuk ulangan harian maupun yang digunakan oleh sekolah untuk ulangan umum belum mengarah kepada penyelesaian masalah yang menantang penalaran siswa yang berhubungan dengan penyelesaian soal-soal yang tidak biasanya yang menuntut penyelesaian dengan prosedur non rutin (Ndiung \& Jediut, 2020).

Instrument penilaian berupa soal yang dirancang guru sering bersumber dari buku-buku praktis berupa Lembar Kerja Siswa (LKS) yang banyak dijual di pasaran ataupun dari Bank-Bank soal yang dikoleksi di sekolah. Seperti yang dinyatakan oleh Wicaksono dan Jumanto (2019 : 15) menyatakan bahwa Soal-soal yang dijadikan instrument penilaian oleh guru untuk menguji aspek kognitif siswa biasanya diambil dari berbagai buku atau kumpulan soal-soal ujian. Lebih jauh dijelaskan pula bahwa soal-soal tersebut cenderung hanya menguji aspek ingatan siswa. Disamping itu terdapat banyak buku yang menyajikan materi dengan mengajak siswa untuk belajar secara aktif, sajian konsep sangat sistematis, tetapi sering diakhiri dengan soal evaluasi yang kurang melatih keterampilan berpikir tingkat tinggi (Higher Order Thinking Skills (HOTS) siswa. Ini berarti bahwa soal-soal atau pertanyaan yang dibuat guru sesuai dengan Taksonomi Bloom masih berada pada level C1, C2 ataupun C3. Memang tidak terlalu dipermasalahkan jika soalsoal atau pertanyaan yang dibuat ada yang hanya mengukur kemampuan 
berpikir C1, C2 ataupun C3, akan tetapi kegiatan penilaian tersebut hanya merupakan instrument soal prasyarat untuk merangsang kegiatan berpikir lebih tinggi. Tetapi akan menjadi masalah jika semua soal yang dirancang hanya sebatas pada level $\mathrm{C} 1$, $\mathrm{C} 2$ ataupun paling tinggi sampai $\mathrm{C} 3$. Hal ini menjadi masalah karena paradigma pembelajaran abad 21 sekarang ini menuntut agar siswa memiliki kemampuan berpikir tingkat tinggi (HOTS) seperti yang sudah dijelaskan pada paparan sebelumnya. Seperti yang dinyatakan oleh Sari, dkk. (2019 : 176) bahwa kemampuan berpikir tingkat tinggi atau Higher Order Thinking Skills (HOTS) menjadi suatu kemampuan yang harus dimiliki pada abad 21 ini. Untuk itu guru hendaknya membuat soal-soal atau pertanyaan yang mampu memfasilitasi siswa dalam hal mengembangkan kemampuan berpikir tingkat tingginya (HOTS).

Soal-soal atau pertanyaan yang HOTS itu dibuat dengan tujuan mengukur kemampuan berpikir siswa terutama dalam hal kemampuan analisis, evaluasi ataupun menciptakan suatu produk atau metode praktis yang bisa dimanfaatkan oleh orang lain. Hal ini sesuai dengan pernyataan Ariani dalam (Yuliandini et al., 2019). (2019) yang menyatakan bahwa Pertanyaan yang berbasis HOTS dibuat dengan tujuan untuk mengukur kemampuan berpikir siswa pada level analisis, sintetis, evaluasi, dan bahkan sampai pada kemampuan mencipta dan mengkreasikan. Muara dari kegiatan ini adalah untuk meningkatkan mutu Pendidikan di Indonesia. Oleh sebab itu peningkatan mutu Pendidikan bukan hanya menaikkan tingkat kesulitan soal melainkan secara menyeluruh mulai dari kurikulum (Sofyan. 2019 : 5).

Kurikulum yang diberlakukan di Indonesia saat ini sejak Tahun 2013 adalah Kurikulum 2013. Kurikulum 2013 diberlakukan sebagai upaya untuk menyempurnakan kurikulum-kurikulum sebelumnya dalam rangka mencapai proses pendidikan diharapkan terwujud dengan baik. Kurikulum 2013 prinsip pelaksanaannya menitik beratkan pada terjadinya keseimbangan antara kompetensi sikap (attitude), pengetahuan (knowledge), dan keterampilan (skill) pada pelaku belajar yang dalam hal ini adalah siswa. Ketiga Kompetensi tersebut diterapkan pada semua muatan atau mata pelajaran yang diberikan. Salah satu muatan / mata pelajaran yang dibelajarkan pada Kurikulum 2013 adalah Matematika.

Matematika merupakan salah satu mata pelajaran yang diwajibkan diajarkan di jenjang pendidikan Sekolah Dasar. Hal ini dikarenakan bahwa Mata Pelajaran Matematika merupakan alat bantu untuk penguasaan Teknologi. Oleh karena itu Mata Pelajaran Matematika wajib diperkenalkan sejak usia Sekolah Dasar. Pembelajaran Matematika membuat anak mampu menguasai berbagai pengetahuan dan keterampilan yang memungkinkan mereka untuk memecahkan masalah dalam kehidupannya sehari-hari (Rachmawati, 2008, seperti dikutip Mirawati (Mirawati, 2017). Pembelajaran Matematika yang dilakukan sejak dini berpengaruh besar terhadap perkembangan sikap, pengetahuan dan keterampilan siswa. Seperti yang dinyatakan oleh (Sumardjan, 2017) karakter pembelajaran Matemaika di SD secara umum disamping anak akan berkompetisi dalam menghitung (kognitif), siswa akan berkomunikasi dan berkompetisi sehat dengan temantemannya (afektif) serta dapat melaksanakan tugas-tugasnya seperti menjual dan membeli. Begitu pentingnya Mata Pelajaran Matematika yang konsepnya mampu mempermudah kesulitan siswa dalam penguasaan teknologi berbanding terbalik dengan kemampuan belajar Matematika Siswa.

Pada kenyataannya kemampuan belajar Matematika siswa di Indonesia masih sangat rendah. Seperti yang disampaikan oleh (Harususilo, 2019) bahwa Pengukuran yang dilakukan oleh Programe for International Sudent Penilaian (PISA) dengan bantuan 
Organization for Economic Cooperation and Development (OECD) untuk Indonesia pada Tahun 2018 dengan melibatkan 12.098 siswa dari 399 sekolah di Indonesia diperoleh skor untuk Matematika sebesar 379 jauh di bawah skor yang diperoleh China dan Singapura yang masing-masing memperoleh skor 591 dan 569. Berdasarkan capaian skor tersebut, Indonesia menempati urutan ke 73 dari 79 negara yang dilakukan pengukuran. Terjadi trend penurunan capaian skor pada Tahun 2018 sebesar 7 poin dibandingkan dengan Tahun 2015 yang mencapai skor 386. Ini adalah sinyal negatif bagi Pemerintah Indonesia untuk sesegera mungkin melakukan evaluasi terhadap proses pendidikan khususnya untuk meningkatkan kemampuan Matematika Siswa.

Permasalahan yang sering muncul dalam pembelajaran Matematika adalah lemahnya kemampuan siswa dalam menggunakan kemampuan berpikirnya untuk menyelesaikan masalah. Khusus untuk Materi Pengolahan Data dalam Kehidupan Sehari-hari yang menjadi topik dalam penelitian ini dari berbagai ujian yang dilakukan baik dalam bentuk ujian sekolah maupun ujian Nasional hasil yang diperoleh siswa sangatlah tidak memuaskan. Seperti misalnya Hasil Ujian Sekolah yang diselenggarakan pada Tahun 2019 (sebelum adanya pandemi Covid-19) dimana untuk Mata Pelajaran Matematika diujikan dengan soal berjumlah 35 buah. Dari 35 buah soal tersebut 7 diantaranya adalah soal dalam bentuk pengolahan data. Dari 7 buah soal tersebut 5 diantaranya merupakan soal dengan level HOTS.
Berdasarkan hasil ujian sekolah yang dilakukan terhadap 42 orang siswa Kelas 6D di SD Negeri 1 Dajan Peken Tabanan Sebanyak 69\% siswa mengalami kesulitan untuk menjawab soal Pengolahan data terutama jenis soal berbasis HOTS pada materi tersebut. Hal ini terjadi karena siswa kurang terlatih dalam mengerjakan soalsoal (HOTS).

Berdasarkan pada paparan
tersebut maka perlu dibuat pengembangkan intrumen penilaian yang berkualitas untuk menghasilkan kualitas pembelajaran yang baik di sekolah dasar. Oleh sebab itu, dilakukan penelitian pengembangan yang berjudul "Pengembangan Instrumen Asesment berbasis HOTS pada Materi Pengolahan Data dalam Kehidupan Sehari-hari untuk Siswa Kelas VI SD".

\section{METODE}

Penelitian ini menggunakan rancangan penelitian pengembangan Research and Development. Penelitian yang dilakukan berupa pengembangan instrument yang dipakai dalam mengukur tingkat validitas, reliabelitas, objektivitas, praktikalitas dan norma. Penelitian dalam bentuk pengembangan dilakukan untuk menciptakan produk, konsep, metode, alat, program atau cara yang bisa mempermudah dan mengatasi permasalahan yang dihadapi oleh manusia (Prasetyo. 2015 : 42). Sedangkan (Sugiyono, 2015) menyatakan bahwa penelitian pengembangan digunakan untuk menghasilkan produk tertentu yang bersifat analisis dan menguji keefektifan produk tersebut.

Tabel 1. Distribusi Subjek Penelitian

\begin{tabular}{|c|c|c|}
\hline No & Subjek & Jumlah \\
\hline 1 & Dosen Ahli & 2 \\
\hline 2 & Guru Kelas VI SD & 3 \\
\hline 3 & Siswa Kelas VI SD & 30 \\
\hline & Banyaknya subjek penelitian & 35 \\
\hline
\end{tabular}


Pengumpulan data yang dilakukan dalam penelitian ini adalah pengumpulan data instrument Penilaian berbasis HOTS dalam bentuk tes pilihan ganda (obyektif). Teknik pengumpulan datanya dapat dilihat pada Tabel berikut::

Tabel 2. Teknik Pengumpulan Data Instrumen

\begin{tabular}{|c|c|c|c|}
\hline No & Jenis Data & Metode Pengumpulan Data & Instrumen \\
\hline \multirow[b]{2}{*}{1} & Validitas isi & $\begin{array}{l}\text { Pernyataan berupa saran dan masukan dari } \\
\text { dosen ahli }\end{array}$ & $\begin{array}{l}\text { Lembar } \\
\text { Penilaian } \\
\text { Respon Ahli }\end{array}$ \\
\hline & Validitas Butir & $\begin{array}{l}\text { Uji coba menggunakan responden siswa } \\
\text { sebanyak } 30 \text { orang siswa Kelas VI SD } \\
\text { menggunakan Google Form }\end{array}$ & $\begin{array}{l}\text { Hasil jawaban } \\
\text { siswa yang } \\
\text { diunduh dari } \\
\text { Google Drive }\end{array}$ \\
\hline 2 & Reliabilitas & $\begin{array}{l}\text { Uji Coba dengan menggunakan reponden } \\
\text { siswa sebanyak } 30 \text { siswa kelas VI SD } \\
\text { menggunakan google form }\end{array}$ & Tes Obyektif \\
\hline 3 & Objektivitas & $\begin{array}{l}\text { Hasil pemeriksaan jawaban siswa yang } \\
\text { dilakukan oleh } 3 \text { orang praktisi guru. }\end{array}$ & $\begin{array}{l}\text { Lembar } \\
\text { penilaian } \\
\text { response } \\
\text { praktisi }\end{array}$ \\
\hline 4. & Praktikalitas & $\begin{array}{l}\text { Pernyataan yang diperoleh dari guru dalam } \\
\text { bentuk check list. }\end{array}$ & $\begin{array}{l}\text { Lembar angket } \\
\text { respon guru }\end{array}$ \\
\hline 5. & Norma & $\begin{array}{l}\text { Menelaah cara penentuaan KKM Satuan } \\
\text { Pendidikan di SD Negeri } 1 \text { Dajan Peken, SD } \\
\text { Negeri } 8 \text { Dajan Peken, dan SD Saraswati } \\
\text { Tabanan. }\end{array}$ & $\begin{array}{l}\text { Dokumen } \\
\text { sekolah. }\end{array}$ \\
\hline
\end{tabular}

Uji validitas yang dicari dilakukan dengan melakukan analisis terhadap validitas isi dan validitas butir dari instrumen yang dibuat dengan bantuan Microsoft Excel pada komputer. Penghitungan Uji validitas isi menggunakan teknik analisis Content Validity Ratio (CVR), formula ini digunakan karena dalam penelitian yang dilakukan melibatkan lima orang pakar dengan alternatif penskoran 3 untuk kategori relevan dan 1 untuk kategori tidak relevan. Hasil penilaian yang diberikan oleh pakar dilakukan penghitungan dengan formula yang dikemukakan pertama kali oleh (Lawshe, 1975). Rumus yang digunakan untuk penghitungan adalah $R=\frac{n e-\frac{N}{2}}{\frac{N}{2}}$.

Setelah memperoleh hasil validasi isi dari instrument assessment berbasis HOTS maka draf II yang telah direvisi diujicobakan kepada 30 orang siswa. Hasil uji coba tersebut kemudian dianalisis untuk menentukan tingkat validitas butir dan reliabilitas tes tersebut.

Uji validitas butir dilakukan dengan menggunakan rumus korelasi teknik korelasi point biserial, formula yang dipakai adalah sebagai berikut $r_{p b i}=$ $\frac{M_{P}-M_{t}}{S_{t}} \sqrt{\frac{p}{q}}$, suatu butir tes akan dinyatakan valid jika setiap butir tes yang dibuat tersebut dalam penghitungan mendapatkan $r_{\text {hitung }}$ lebih besar daripada $r_{\text {tabel }}$ dengan taraf signifikansi $5 \%\left(r_{\text {hitung }}>r_{\text {tabel }}\right.$ dengan t.s. $5 \%)$.

Uji reliabilitas dilakukan menggunakan 30 orang responden yang berasal dari siswa kelas VI SD di tiga sekolah berbeda di kecamatan Tabanan. Pengujian dilakukan menggunakan teknik DARING (dalam Jaringan) memanfaatkan fasilitas google form. Penghitungan uji reabilitas dilakukan dengan menggunakan rumus 
$K R 21$ yaitu :

$$
\mathrm{r}_{11}=\frac{k}{k-1}\left\{1-\frac{M^{t}\left(k-M^{t}\right)}{k \cdot S_{t}^{2}}\right\}
$$

(Candiasa, 2010)

Tingkat objektivitas instrument dianalisis dengan cara mengkorelasikan hasil penilaian atau penskoran yang diberikan pada setiap siswa oleh penilai satu dengan penilai yang lainnya. Hasil korelasi tersebut kemudian dilakukan analisis untuk mengetahui apakah ada perbedaan pensekoran yang diberikan oleh penilai satu dengan penilai yang lainnya. Pensekoran yang dimaksud adalah memberikan skor 1 untuk jawaban siswa yang benar dan 0 (nol) untuk jawaban siswa yang salah. Jika terdapat perbedaan maka tingkat objektivitas soal diragukan. Untuk memperkecil potensi tidak objektifnya penilai maka pada saat penilai (guru) memeriksa jawaban siswa, maka identitas siswa tidak dimunculkan, hanya berupa keterangan responden 1 , 2, 3, dst.

Analisis tingkat kepraktisan instrument (Praktikalitas) dilakukan dengan melakukan uji kepraktisan oleh guru. Penilaian instrumen berdasarkan pada lembar angket yang sudah diisi oleh praktisi (guru) dianalisis untuk mengetahui tingkat kepraktisan dari produk yang dikembangkan. Penskoran untuk masing-masing komponen dilakukan dengan skala likert. Berikut adalah analisis kepraktisan sesuai dengan skala likert yaitu:

a. Memberikan skor untuk setiap item jawaban. Setiap item jawaban diberikan skor dari rentang $1 \mathrm{sd}$. 4 . Berikut adalah tabel pensekoran yang dimaksud.

Tabel 3. Tabel Skala Likert

\begin{tabular}{cl}
\hline Skor & \multicolumn{1}{c}{ Kriteria } \\
\hline 4 & Sangat setuju \\
3 & Setuju \\
2 & $\begin{array}{l}\text { Tidak setuju } \\
\text { Sangat tidak } \\
\text { setuju }\end{array}$ \\
& Sugiono : $2012: 34)$
\end{tabular}

b. Menjumlahkan skor total untuk seluruh komponen

c. Analisis Praktikalitas dilakukan menggunakan persentase (\%)

Nilai Praktikalitas $=$ $\frac{\text { Jumlah perolehan skor }}{\text { skor maksimum }} \times 100 \%$.

d. Menetapkan kriteria terhadap praktikalitas instrument.

Setelah Nilai Praktikalitas diperoleh maka nilai tersebut dikelompokkan sesuai dengan tabel kriteria berikut :

Tabel 4. Tabel Kriteria uji praktikalitas

\begin{tabular}{ccl}
\hline No. & Nilai & \multicolumn{1}{c}{ Kriteria } \\
\hline 1. & $0-20$ & Tidak praktis \\
2. & $21-40$ & Kurang praktis \\
3. & $41-60$ & Cukup praktis \\
4. & $61-80$ & Praktis \\
5. & $81-100$ & Sangat Praktis \\
\hline & & (Riduwan, 2004)
\end{tabular}

Analisis uji norma dilakukan dengan menganalisis hasil jawaban siswa untuk ditetapkan ketuntasannya dalam menguasai Kompetensi Dasar terkait dengan KD. 3.8 pada pembelajaran Matematika di Kelas VI SD. Data yang diperoleh dari jawaban siswa terhadap instrumen soal yang diberikan dalam bentuk google form dianalisis tingkat pencapaiannya dengan menjumlahkan skor yang diperoleh. Hasil pencapaian siswa tersebut dihitung dengan rumus Nilai Pencapaian $=\frac{\text { Jumlah perolehan skor }}{\text { skor maksimum }} \times 100$. Hasil analisis tersebut dikorelasikan dengan KKM yang ditetapkan oleh masingmasing Sekolah.

\section{HASIL DAN PEMBAHASAN}

Penelitian yang dilakukan dirancang dalam bentuk pengembangan terhadap instrumen Penilaian berbasis HOTS. Instrument dibuat dalam bentuk soal obyektif dengan jenis tes multiple choice dengan pilihan jawaban lebih dari satu. Instrument yang dibuat tersebut digunakan untuk memfasilitasi serta memberikan pengalaman kepada siswa Kelas VI SD agar bisa berpikir HOTS. Instrument yang dibuat dibatasi pada Mata Pelajaran Matematika materi 
Pengolahan Data dalam Kehidupan Sehari-hari yang ada pada pembelajaran di Kelas VI SD. Model pengembangan yang digunakan dalam penelitian ini adalah model pengembangan 4-D (Four D). Model ini pertama kali dikembangkan oleh (Thiagarajan, 1974) yang terdiri atas empat tahap utama yaitu : Define (Pendefinisian), Design (Perancangan), Develop (Pengembangan) dan Disseminate (Penyebaran). Penerapan tahapan tersebut pada penelitian ini dilaksanakan hanya melalui tahap define, design dan develop sedangkan tahap disseminate belum bisa dilakukan karena adanya sebuah pandemi Virus Covid-19 yang menyebabkan pembelajaran tidak bisa dilakukan secara tatap muka. Ketiga tahapan tersebut dapat dijelaskan secara singkat sebagai berikut:

1. Tahap Pendefinisian (Define).

Tahap pendefinisian merupakan tahap dalam hal menetapkan dan mendefinisikan syarat syarat yang diberlakukan dalam kegiatan pembelajaran. Kegiatan pendefinisian, meliputi analisis awal-akhir, analisis siswa, analisis konsep, dan perumusan tujuan pembelajaran.

Kegiatan analisis awal-akhir dilakukan untuk mengkaji masalah dasar yang diperlukan dalam pengembangan instrumen tes kemampuan berpikir tingkat tinggi. Pada tahap ini dilakukan telaah terhadap kompetensi dasar (KD) kelas VI semester II yang berkaitan dengan materi Pengolahan Data dalam Kehidupan Sehari-hari sehingga memudahkan langkah awal dalam mengembangkan intrumen pengukuran atau tes-tes kemampuan berpikir tingkat tinggi yang sesuai untuk dikembangkan. Hasil yang diperoleh pada tahap ini adalah terdapat dua KD yang berbasis HOTS dengan KKO level C5 yaitu KD 3.2 dan KD 3.4 dan 2 KD lainnya berbasis LOTS. KD 3.4 merupakan KD untuk membelajarkan materi
Pengolahan Data, sehingga bisa dibuatkan instrument HOTS.

Analisis siswa dilakukan dengan kegiatan wawancara yang dilakukan ke 30 orang siswa pada tanggal 17 Februari 2021 melalui aplikasi Zoom didapatkan hasil bahwa siswa belum berpengalaman dalam mengerjakan soal-soal yang Berbasis HOTS khususnya dalam Materi Pengolahan Data dalam Kehidupan Sehari-hari. Akibatnya kemampuan siswa dalam mengerjakan soal yang berbasis HOTS terkait dengan materi tersebut rendah. Siswa mengalami kebingungan ketika dihadapkan pada soal yang berbasis HOTS karena sebelumnya tidak pernah diberikan latihan-latihan soal berbasis HOTS.

Analisis konsep Analisis konsep yang dilakukan dalam penelitian ini adalah dengan mengidentifikasi, merinci dan menyusun secara sistematis Materi Pengolahan Data dalam Kehidupan Sehari-hari yang ada pada Mata Pelajaran Matematika untuk Siswa Kelas VI SD pada Semester 2 (genap). Konsep Materi ini sangatlah penting untuk dipelajari dan dikuasai oleh siswa. Karena Materi ini merupakan materi pembelajaran untuk memperkenalkan konsep Statistika dasar bagi siswa. Oleh karena itu materi ini selalu diujikan pada setiap Ujian Nasional maupun Ujian Sekolah yang dilangsungkan setiap tahunnya. Setiap diadakan ujian Nasional maupun Ujian Sekolah Sebagian besar soal yang terkait dengan Materi Pengolahan Data dalam Kehidupan sehari-hari Sebagian besar berbasis HOTS. Seperti pada soal yang ditemukan pada Ujian Sekolah pada Tahun 2019 sebanyak 5 dari 7 soal terkait materi ini adalah soal berbasis HOTS.

Tahap perumusan tujuan dibuat dengan tujuan untuk merancang kerangka konsep dari analisis awal, analisis siswa dan analisis konsep menjadi tujuan khusus yaitu untuk mengembangkan instrumen Penilaian Berbasis HOTS pada Materi Pengolahan Data dalam Kehidupan 
Sehari-hari untuk Siswa Kelas VI SD pada Semester 2. Tujuan khusus yang dimaksud dalam penelitian ini adalah pembuatan instrument penilaian berbasis HOTS yang Valid, Reliabel, objektif, praktis dan norma sehingga bisa digunakan oleh Guru Kelas VI SD untuk melatih kemampuan berpikir tingkat tinggi (HOTS) pada siswa.

\section{Tahap Perancangan (Design)}

Tahap perancangan (design) digunakan untuk merancang bentuk dasar dari instrumen pengukuran keterampilan berpikir tingkat tinggi siswa. Pada tahap ini memuat kegiatan seperti :

\section{a. Penyusunan Tes}

Dasar dari penyusunan soal adalah analisis Kompetensi Dasar (KD) yang dibelajarkan terkait dengan Materi Pengolahan Data dalam Kehidupan Sehari-hari. Hasil analisis tersebut yang berupa pengkajian terhadap Kata Kerja Operasional (KKO) yang termuat dalam KD dipilih yang berkategori HOTS. Setelah dilakukan analisis terhadap KD kemudian dirancang Indikator Pencapaian Kompetensi (IPK) untuk kemudian dijadikan indikator penyusunan tes dalam bentuk kisi-kisi soal.

b. Pemilihan Format

Pemilihan format dalam pengembangan instrumen Penilaian berbasis HOTS berupa pemilihan format yang dipakai untuk merancang isi dan topik yang diujikan. Berkenaan dengan penelitian ini instrumen tes yang dibuat bertipe analisis (C4) dan Evaluasi (C5). Ini berarti bahwa pada prosesnya kemampuan berpikir siswa yang dikehendaki adalah pada tingkat atau level C4 dan C5 karena untuk merancang instrument penilaian yang berkategori HOTS maka soal yang dibuat mengharuskan aktivitas berpikir yang dikehendaki adalah mulai dari $\mathrm{C} 4$, C5, dan C6.

c. Perancangan Awal

Rancangan awal merupakan rancangan semua instrumen yang dikerjakan sebelum soal bisa untuk diujicobakan. Pada tahap ini dihasilkan sebuah versi awal Draft 1 yang selanjutnya dilakukan revisi terlebih dahulu oleh dosen pembimbing. Draft I ini selanjutnya disempurnakan melalui serankaian proses yang dilakukan pada tahapan pengembangan.

\section{Tahap Pengembangan (Develop)}

Soal tes disusun berdasarkan pada analisis konsep dan analisis tugas yang dijabarkan ke dalam spesifikasi instrumen pengukuran kemampuan berpikir tingkat tinggi, selanjutnya dibuatkan kisi-kisi dan acuan penskorannya menurut dimensi kemampuan berpikir tingkat tinggi.

Tes yang disusun sesuai kisi-kisi tersebut kemudian dikirimkan ke para pakar atau ahli agar bisa diberikan penilaian. Sebelum diberikan penilaian soal tersebut terlebih dahulu dilakukan penyempurnaan berdasarkan petunjuk, saran dan masukan dari para ahli tersebut. Masukan atau saran yang diberikan oleh ahli tersebut terkait dengan indikator penilaian yang disusun agar lebih spesifik mampu menggambarkan bentuk soal. Masukan lainnya adalah terkait dengan pembuatan pilihan jawaban dalam bentuk option agar option tersebut tidak terlalu melebar konteksnya sehingga pilihan jawaban yang dikehendaki bisa dibatasi. Soal yang dibuat juga harus memperhatikan pemilihan Bahasa yang pas dan mudah dipahami oleh siswa. Terkait dengan variasi soal maka soal yang dibuat berdasarkan masukan ahli agar mampu memfasilitasi siswa yang pintar dengan tanpa mengesampingkan siswa yang kemampuan berikirnya tergolong lambat. Secara keseluruhan penilaian yang diberikan oleh semua pakar menyatakan soal relevan dan bisa diujicobakan ke siswa. Sebelum diujicobakan ke siswa maka instrument soal yang dibuat setelah mengalami beberapa perbaikan perlu dilakukan uji validitas isi.

Uji Validitas isi instrument sangat penting untuk dilakukan. Karena tinggi rendahnya indeks validitas suatu 
instrument akan sangat berpengaruh terhadap keakuratan suatu hasil pengukuran (Harmurni, 2019). Validitas isi instrument ditetapkan berdasarkan hasil validasi oleh pendapat ahli (expert judgments) praktisi pendidikan untuk Mata Pelajaran Matematika Materi "Pengolahan Data dalam Kehidupan Sehari-hari". Valid atau tidaknya suatu butir soal ditetapkan berdasarkan kriteria yang sudah dibuat serta mengacu pada jumlah judges yang dilibatkan.

Butir soal dikatakan valid jika nilai CVR $\geq 1,00$. Sebaliknya jika CVR < 1,00 maka butir soal dinyatakan tidak valid. Setelah dilakukan uji validitas isi dengan CVR dan didapatkan semua soal valid maka soal tersebut diujicobakan menggunakan Google Form dengan jumlah siswa sebagai responden adalah 30 orang dari tiga sekolah yang berbeda.

Berdasarkan hasil pengujian soal kepada 30 orang siswa, maka selanjutnya dilakukan uji terhadap validitas butir soal. Hasil uji dihitung menggunakan rumus korelasi point biserial. Penghitungan dilakukan dengan memanfaatkan bantuan program Microsoft Office Excel pada komputer. Berdasarkan hasil perhitungan didapatkan hasil bahwa soal nomor 1 rpbis $=0,585$, soal nomor 2 rpbis $=$ 0,437 , soal nomor 3 rpbis $=0,551$, soal nomor 4 rpbis $=0,466$, soal nomor 5 rpbis $=0,491$, soal nomor 6 rpbis $=$ 0,495 , soal nomor 7 rpbis $=0,561$, sola nomor 8 rpbis $=0,509$, soal nomor 9 rpbis $=0,400$, soal nomor 10 rpbis $=$ 0,682 , soal nomor 11 rpbis $=0,559$, soal nomor 12 rpbis $=0,485$, soal nomor 13 dan 14 rpbis $=0,466$, soal nomor 15 rpbis $=0,412$. Berdasarkan taraf signifikansi $5 \%$ untuk soal dengan jumlah 15 rtab $=0,361$ maka rpbis $>$ rtab sehingga semua soal dinyatakan valid untuk setiap butirnya. Setelah selesai dilakukan uji validitas butir dan semua soal valid, kemudian dilanjutkan terhadap uji reliabelitas.
Proses penghitungan Uji reliabilitas instrumen berupa penilaian pada keterampilan berpikir tingkat tinggi (HOTS) menggunakan rumus KR 21.

Penghitungan uji reliabelitas instrumen dilakukan dengan bantuan aplikasi Microsoft Office Excel. Dalam uji reliabilitas ini menggunakan 30 siswa kelas VI SD yang dijadikan sebagai responden. Berdasar pada hasil uji reliabilitas instrumen didapatkan nilai sebesar 0,75 . Hasil ini memperlihatkan bahwa reliabilitas berada pada rentang $0,60<r_{1.1} \leq 0,80$ atau tepatnya berada pada kategori derajat reliabilitas "tinggi" berdasarkan kriteria derajat reliabilitas tes menurut Guilford dalam (Koyan, 2012).

Sesuai dengan hasil perhitungan yang dilakukan diperoleh nilai CVR dari 15 butir soal yaitu 1,00 artinya semua soal dinyatakan valid. (Masitoh \& Aedi, 2020) menyatakan bahwa apabila hasil uji reliabilitas berada pada kategori tinggi atau sangat tinggi maka instrumen tersebut bisa dikatakan ajeg, sehingga instrumen yang telah disusun reliabel.

Tingkat objektivitas didapatkan dari hasil analisis nilai capaian siswa oleh ketiga guru terkait dengan jawaban siswa terhadap soal. Misalnya Guru 1 setelah melakukan analisis jawaban responden 1 mendapat nilai capaian 33, Guru 2 dan 3 juga mendapatkan Nilai capaian yang sama yaitu 33. Begitupun untuk responden 2 sd 30 diberikan capaian yang tidak ada bedanya antara guru 1 dengan guru lainnya. Konsep objektivitas adalah kegiatan penilaian yang dilakukan oleh seseorang yang dalam hal ini adalah guru yang jauh dari unsur-unsur subjektivitas. Subjektivitas yang dimaksud disini adalah penilaian yang dilakukan oleh guru yang bukan berdasarkan adanya hubungan khusus antara guru dengan siswa yang dinilai sehingga mempengaruhi hasil penilaian.

Tingkat objektivitas akan terlihat jika tingkat penilaian atau pengukuran yang dilakukan oleh dua orang atau lebih pengetes hasilnya seragam siswa atau kelompok siswa yang sama (Susilawati, 2018). Oleh karena 
instrument dalam penelitian ini sudah dilakukan pengujian oleh tiga orang penguji dan ketiganya memperoleh skor capaian yang sama terhadap siswa maka instrumen Penilaian Berbasis HOTS sudah memenuhi unsur-unsur objektivitas sehingga instrument bisa dikatakan objektif.

Uji Praktikalitas instrument dilakukan terkait dengan hasil analisis angket yang mengandung komponen Kemudahan, Efisiensi, dan Manfaat. Berdasarkan uji yang dilakukan didapatkan hasil untuk komponen Kemudahan adalah 92, Efisiensi adalah 92 dan Manfaat adalah 94. Sesuai dengan tabel korelasi ketiga komponen tersebut berada pada rentang nilai 80 sd 100 (tabel korelasi skala Likert). Pada tabel korelasi tersebut menjelaskan bahwa jika hasil penghitungan instrument berada pada rentang $80 \mathrm{sd}$ 100 maka instrument tersebut berada pada kategori "Sangat Praktis".

hasil analisis terhadap uji norma yang dilakukan terhadap instrument didapatkan hasil bahwa sebanyak 22 orang siswa atau $73 \%$ mencapai nilai di atas atau sama dengan KKM Sekolah, dan 8 orang siswa atau $27 \%$ mendapatkan nilai di bawah KKM sekolah. Berdasarkan pada konsepsi norma yang sudah dijalaskan dalam penelitian ini bahwa norma merupakan patokan atau kriteria yang dibuat untuk menetapkan kelulusan atau ketuntasan siswa. Sesuai dengan Buku Panduan Penilaian Kurikulum 2013 yang dikeluarkan oleh Kemdikbud bahwa setiap satuan Pendidikan atau Sekolah harus melakukan analisis keadaan atau potensi Sekolahnya untuk membuat Kriteria Ketuntasan Minimal (KKM) sebagai patokan untuk menentukan keberhasilan proses pembelajaran dan penilaian yang dilakukan oleh sekolah.

Berdasarkan hasil analisis dan pembahasan hasil penelitian yang ditemukan, dapat memberikan beberapa implikasi terhadap pengembangan instrumen Penilaian Berbasis HOTS di SD, implikasi temuan peneliti adalah sebagai berikut.
1. Pemanfaatan instrumen pada proses pengukuran terhadap proses dan hasil kegiatan belajar harus disesuaikan dengan KD dan indikator yang dibuat. selanjutnya guru hendaknya mempunyai kemampuan untuk menganalisis KD sehingga bisa merancang suatu kegiatan pembelajaran maupun proses penilaian yang Berbasis HOTS.

2. Instrumen Berbasis HOTS secara otomatis merangsang siswa untuk dapat mengembangkan kemampuan berpikir tingkat tingginya (HOTS) yang bukan hanya pada proses penghafalan dan pemahaman terhadap fakta atau konsep melainkan lebih pada proses pemaknaan terhadap suatu fenomena melalui kegiatan analisis, evaluatif dan kreatif.

3. Guru hendaknya bisa merancang dan mengembangkan kegiatan penilaian yang bersifat otentik (Authentic Penilaian). Penilaian otentik (Authentic Penilaian) merupakan penilaian yang dilakukan secara menyeluruh yang mencakup ranah afektif (sikap), kognitif (pengetahuan) dan psikomotor (keterampilan). Perancangan kegiatan penilaian bersifat otentik tersebut tergambar dari RPP yang dibuat oleh guru.

Penggunaan instrumen Penilaian Berbasis HOTS ini diperoleh gambaran, siswa menjadi terlatih untuk berpikir kritis, logis dan memiliki kemampuan saintifik dalam memecahkan setiap permasalahan yang diberikan. Suatu permasalahan yang dihadapi oleh siswa akan dipecahkan menggunakan penalaran yang tidak hanya berdasarkan pada proses mengingat, memahami, menerapkan kaidah atau teori tatapi siswa sudah mampu menganalisa bahkan memberikan penilaian terhadap suatu permasalahan. Sebelumnya siswa jarang bahkan ada yang tidak pernah sama sekali diberikan kesempatan untuk mengembangkan kemampuan berpikirnya sampai pada 
tingkat analisis, evaluattif atau sampai pada tingkat creativity akan tetapi tiba saatnya dilakukan Ujian bersekala nasional yang mana tes yang diberikan ke siswa (pada Tahun 2019) 30\% diantaranya berkategori HOTS maka disana siswa akan menemukan kesulitan dalam mengerjakan soal tersebut. Hal ini sesuai dengan penelitian yang dilakukan oleh (Rusudianto et al., 2020) menyatakan bahwa "jarangnya guru memberikan soal-soal yang menuntut kemampuan berpikir tingkat tinggi kepada peserta didik, maka siswa tidak akan memiliki kemampuan untuk berpikir dan memecahkan suatu permasalahan". Pada proses pembelajaran yang dilakukan oleh guru juga tidak mencerminkan kegiatan belajar yang menggambarkan suasana HOTS. Penilaiannya bersifat HOTS maka pembelajarannya juga dirancang mengarah ke kegiatan belajar yang Berbasis HOTS.

Kemudian berdasarkan hasil observasi yang dilakukan oleh (Poerwanti \& Tribudhiarto, 2020) menyatakan bahwa pada kegiatan program pengalaman lapangan dan kegiatan pendidikan profesi guru (PPG) di sekolah dasar negeri di Kecamatan Laweyan, sebagian besar instrumen yang dirancang oleh guru masih bersifat low or middle order thinking skills. Ini berarti bahwa instrument soal yang dirancang guru kurang mampu melatih siswa untuk berpikir kritis dalam memecahkan masalah, baik permasalahan dalam pembelajaran maupun dalam kehidupan sehari-hari. Instrumen yang dirancang guru juga sebagian besar kurang mengacu pada kompetensi dasar (KD), dan indikator pencapaian kompetensi (IPK), karena pada proses perancangannya hanya terfokus pada materi ajar, sedangkan ada beberapa materi ajar yang kurang sesuai dengan kompetensi dasar yang terdapat pada silabus pembelajaran. Implikasi dari kekurang pahaman guru dalam menyusun instrument yang Berbasis HOTS berimbas pada siswa yang kurang diberikan pengalaman untuk menyelesaikan permasalahan yang menuntut kemampuan berpikir tingkat tinggi (HOTS). Seperti penelitian yang dilakukan oleh (Saraswati, 2019) yang menyatakan bahwa siswa kelas $\mathrm{V}$ SDN 1 Padang Sambian Tahun Ajaran 2019/2020 cenderung mempunyai Kemampuan Berpikir HOTS "Cukup" serta masih rendah kemampuannya dalam menyelesaikan soal ranah kognitif C6. Disamping itu siswa kelas V SDN 1 Padang Sambian cenderung mendapat kesulitan Ketika dihadapkan pada kegiatan membuat/membentuk kalimat matematika.

Mengacu kepada hasil analisis dan hasil kajian dalam penelitian lainnya yang sejalan dengan penelitian ini, dapat disimpulkan bahwa hasil analisis yang diperoleh yaitu analisis uji validitas isi dengan CVR, validitas butir dengan Point Bisserial dan analisis uji reliabilitas dengan KR21, ditambah lagi dengan uji objektivitas, praktikalitas, serta norma maka instrumen Penilaian Berbasis HOTS pada Materi Pengolahan Data dalam Kehidupan Sehari-hari merupakan instrumen yang valid, reliabel, objektif, praktis dan norma.

\section{PENUTUP}

Berdasarkan hasil analisis data melalui uji validitas isi menggunakan Teknik (Lawshe, 1975) yaitu Content Validity Ratio (CVR) diperoleh 30 butir soal valid dengan nilai CVR $=1,00$. Uji validitas butir dilakukan dengan menggunakan rumus point biserial diperoleh setiap butir soal mempunyai $r_{\text {hitung }}>r_{\text {tabel }}$ ini berarti setiap butir soal dinyatakan valid. Soal yang valid belum tentu reliabel sehingga diperlukan uji reliabilitas menggunakan KR21untuk menentukan reliabel atau tidaknya instrument Assesmen berbasis HOTS. Berdasarkan pada hasil uji reliabilitas tersebut maka diperoleh nilai 0,75 dan berada pada rentang $0,60<r_{1.1} \leq 0,80$ ini berarti bahwa soal yang dijadikan instrument penelitian berada pada kategori derajat reliabilitas yang tinggi 
sehingga sesuai dengan grand teori yang sudah dipaparkan soal tersebut sudah ajeg dan boleh untuk diujicobakan.

\section{DAFTAR RUJUKAN}

Candiasa, I. M. (2010). Pengujian Instrumen Penelitian Disertai Aplikasi ITEMAN dan BIGSTEPS. Undiksha Press.

Harmuni, L. (2019). Instrumen Penilaian dan Validasinya. Uwais Inspirasi Indonesia.

Harususilo, Y. E. (2019). Skor PISA Terbaru Indonesia. Compas.Com. https: // edukasi. kompas.com /read/2019/12/04/13002801/ skorpisa-terbaru- indonesia-ini-5-prbesar-pendidikan-pada-eranadiem-makarim

Hidayati, A. U. (2017). Melatih Keterampilan Berpikir Tingkat Tinggi dalam Pembelajaran Matematika pada siswa Sekolah Dasar.

Janah, S. R., Suyitno, H., \& Rosyida, I. (2019). Pentingnya Literasi Matematika dan Berpikir Kritis Matematis dalam Menghadapi Abad ke-21. PRISMA, Prosiding Seminar Nasional Matematika, 2, 905-910.

https://journal.unnes.ac.id/sju/index .php/prisma/article/download/29305 $/ 12924$

Koyan. (2012). Statistik Pendidikan teknik analisis data kuantitaif. Undiksha.

Lawshe, C. H. (1975). quantitative approach to content validity. Jurnal Personnel Psychology, Vo. 28, No.

Masitoh, L. F., \& Aedi, W. G. (2020). Pengembangan Instrumen Asesmen Higher Order Thinking Skills (HOTS) Matematika di SMP Kelas VII. Jurnal Cendekia: Jurnal Pendidikan Matematika, 4(2), 886897.

https://doi.org/10.31004/cendekia.v
$4 \mathrm{i} 2.328$

Mirawati. (2017). Matematika Kreatif: Pembelajaran Matematika Bagi Anak Usia Dini Melalui Kegiatan Yang Menyenangkan Dan Bermakna.

Ndiung, S., \& Jediut, M. (2020). Pengembangan instrumen tes hasil belajar matematika peserta didik sekolah dasar berorientasi pada berpikir tingkat tinggi. Premiere Educandum: Jurnal Pendidikan Dasar Dan Pembelajaran, 10(1), 94.

https://doi.org/10.25273/pe.v10i1.6 274

Poerwanti, J. I. S., \& Tribudhiarto. (2020). Pelatihan Merancang Instrumen Asesmen High Order Thinking Skills Pada Guru-Guru SD Di Kecamatan Laweyan Surakarta. Jurnal Widya Laksana, 9(1), 68.

Riduwan. (2004). Belajar Mudah untuk Guru Karyawan dan Peneliti Pemula. Alfabeta.

Rusudianto, A. R., Susanta, A. S., \& Muktadir, A. M. (2020). Pengembangan Instrumen Penilaian Berbasis Higher Order Thinking (Hot) Pelajaran Matematika Kelas IV Sekolah Dasar. Jurnal Pembelajaran Dan Pengajaran Pendidikan Dasar, 3(1), 1-19. https://doi.org/10.33369/dikdas.v3i1 .12110

Sani, A. H. (2015). Pembelajaran Matematika Berbasis Pendekatan Saintifik dan Kaitannya Dengan Menumbuhkan Keterampilan Berpikir Tingkat Tinggi. Jurnal Pendidikan Seminar Nasional Matematika Dan Pendidikan Matematika UNY, 57-62. seminar.uny.ac.id/semnasmatemati $\mathrm{ka} / \mathrm{sites} /$ seminar.uny.ac.id.semnas matematika/files/banner/PM-9.pdf

Saraswati, P. M. S. (2019). Kemampuan Berpikir Tingkat Tinggi Dalam 
Menyelesaikan Soal HOTS Mata Pelajaran Matematika. Jurnal IImiah Sekolah Dasar, 4(2), 257269.

Sofyan, F. A. (2019). Implementasi Hots Pada Kurikulum 2013. Inventa, 3(1), $1-9$. https://doi.org/10.36456/inventa.3.1 .a1803

Sugiyono. (2015). Metode Penelitian \& Pengembangan. Alfabeta.

$\begin{array}{cr}\text { Sumardjan. (2017). } & \text { Desain } \\ \text { Pembelajaran } & \text { MTK } \\ \text { Menyenangkan. Formaci Pres. } & \end{array}$

Susilawati, D. (2018). Tes dan Pengukuran. UPI Sumedang Pres.

Thiagarajan. (1974). Instructional Development for Training Teacher of Exceptional Children A sourcebook. Indiana University.

Yuliandini, N., Hamdu, G., \& Respati, R. (2019). Pengembangan Soal Tes Berbasis Higher Order Thinking Skill (HOTS) Taksonomi Bloom Revisi di Sekolah Dasar. PEDADIDAKTIKA: Jurnal IImiah Pendidikan Guru Sekolah Dasar, 6(1), 37-46. 